\title{
LEOPARD Syndrome (Multiple Lentigine Noonan Syndrome)
}

\author{
Ayşenur Saygılı' (D), Mine Ün²(1)
}

\section{LEOPARD SYNDROME}

LEOPARD syndrome (LS) was first described in 1936 by Zeisler and Becker in a 24-year-old woman. Some abnormalities were observed in the first case such as hypertelorism (increased distance between the two organs) and pectus carinatum (deformed the anterior chest wall). Along with these, café au lait (coffee with milk) lentigines were detected. In the later period, new findings were added in isolated patients or families. It was reported in twins as the first family case. ${ }^{[1]}$ Moynahan EJ first identified the association of the syndrome with cardiac abnormalities and short stature in 1962. ${ }^{[2]}$

In 1962, LEOPARD Syndrome was defined with its clinical features by Moynahan EJ. Gorlin RJ suggested LEOPARD as an abbreviation. it is named using the first letters of the findings: Lentigines, Electrocardiographic abnormalities, Ocular hypertelorism, Pulmonary stenosis, Abnormal genitalia, Retardation of growth and Deafness. ${ }^{[3,4]}$

Noonan syndrome is also suspected in people with one or more of the cardinal traits. There are similarities with LEOPARD syndrome. LEOPARD syndrome has a lot of lentigines, so it is also called Noonan syndrome with multiple lentigines (NSML).

'Inönü University Molecular Biology and Genetics Graduate, Malatya, Turkey 2ERBAS Institute of Experimental Medicine, Illinois, USA \& Gebze, Turkey

Correspondence: Mine Ün. Deneysel Tıp Enstitüsü, 41470 Gebze-Kocaeli, Türkiye.

E-mail: : unmine13@gmail.com

Cite this article as: Saygılı A, Ün M. LEOPARD Syndrome (Multiple Lentigine Noonan Syndrome). JEB Med Sci 2020;1(3):131-134.

doi: $10.5606 /$ jebms. 2020.75628

Received : September 11,2020

Accepted : October 26, 2020

Published online : December 29, 2020

(๑2020 Journal of Experimental and Basic Medical Sciences. All rights reserved.

\begin{abstract}
LEOPARD is a syndrome characterized by sensorineural hearing loss and abnormal genitalia in addition to dysmorphic facial features, including diffuse brown spots, cardiac abnormalities, short stature, pectus deformity, widely spaced eyes, and ptosis. LEOPARD consists of the initials of the findings obtained in the cases: Lentigines, Electrocardiographic abnormalities, Ocular hypertelorism, Pulmonary stenosis, Abnormal genitalia, Retardation of growth and Deafness. This syndrome is autosomal dominant. In the syndrome, 4 mutations have been identified in this process from the investigated chromosomes to genes. These are PTPN11, RAF1, BRAF and MAP2K1. While these mutations cause amino acid changes in the genotype, they reveal visible clinical findings in the phenotype. It is also called Multiple Lentigine Noonan Syndrome due to its similarity with Noonan syndrome. Too many dark brown spots are present in individuals with LEOPARD syndrome as a distinctive clinical finding from Noonan syndrome.

Keywords: Amino acid, chromosome, lentigin, LEOPARD syndrome, mutation, Noonan syndrome, signaling pathway.
\end{abstract}

This name was changed to LEOPARD because it was long and was thought to frighten children. In addition, studies have shown that the disease is autosomal dominant inherited. This suggested that it was a genetic disorder. ${ }^{[3,4]}$

Symptoms seen in LEOPARD Syndrome are: brown spots (Lentigine), hypertrophic cardiomyopathy in addition to cardiac abnormalities, weak linear growth/ short stature, dysmorphic facial features including pectus deformity, widely spaced eyes and ptosis plus sensorineural hearing loss, abnormal genital area (e.g. in male cryptorchidism (missing testicle)). When these symptoms are seen in the clinic, a pre-diagnosis can be made. ${ }^{[5,6]}$

\section{GENETIC STRUCTURE OF LEOPARD SYNDROME}

The diagnosis of LEOPARD syndrome is made by visible clinical signs, or by identification of a 
pathogenic variant in one of four genes (PTPN11, RAF1, BRAF, and MAP2K1) if clinical findings are insufficient. ${ }^{[7]}$

\section{LEOPARD SYNDROME AND THE FOUR GENE}

The PTPN11 gene is responsible for making a protein called SHP2. This protein helps regulate the RAS/MAPK signaling pathway. This signal pathway has characteristics such as the growth and division of cells, the maturation process of cells to perform certain functions, cell movement and self-destruction (apoptosis) of cells. During embryonic development, SHP2 protein is very important in the development of the heart, blood cells, bones and many other tissues. ${ }^{[8,9]}$

Multiple lentigines caused by PTPN11 gene mutations are one of two mutations that make up about 65 percent of noonan syndrome cases. Two different mutations occur in the SHP2 protein with the change of amino acids. One of these mutations is the replacement of tyrosine and cysteine, and the other is the replacement of threonine and methionine. ${ }^{[8,9]}$

Approximately $85 \%$ of patients diagnosed with definite LEOPARD syndrome have a mutation in the PTPN11 gene located on the 24.1 location of the $12^{\text {th }}$ chromosome $q$ (long) arm. The PTPN11 gene encodes the PTPase (SHP2) protein, which contains the SRC homology $2(\mathrm{SH} 2)$ domain. $\mathrm{SH} 2$ has two subdomains ( $\mathrm{N}-\mathrm{SH} 2$ and $\mathrm{C}-\mathrm{SH} 2)$. These domains characterize and activate protein tyrosine phosphatase (PTP) domain. SHP2 functions as cytoplasmic signal converter, playing a specific role for growth factors, multiple receptors for cytokines and hormones and in the RAS-mitogenactivated protein kinase (MAPK) pathway. So far 11 different PTPN11 mutations have been reported in exons 7, 12 and 13 (Tyr279Cys/Ser, Ala461Thr, Gly464Ala, Thr468Met/Pro, Arg498Trp/ Leu, GIn506Pro and GIn510Glu/Gly). Two of these (Tyr279Cys and Thr468Met) occur in approximately $65 \%$ of cases. ${ }^{[10-13]}$

Sporadic tumors (including leukemia and solid tumors) that occur in the absence of NSML (LEOPARD Syndrome) or other findings of Noonan syndrome contain somatic pathogenic variants in PTPN11 that are not found in reproductive cells; therefore, predisposition to these tumors is not inherited. PTPN11 cancer are benign tumors. ${ }^{[2]}$

\section{BRAF}

Sithanandam et al. ${ }^{[7]}$ Succeeded in cloning BRAF from the CDNA library in 1990 using a BRAF kinasespecific oligomer. The BRAF gene has 651 amino acids and its total molecular weight is $72.5 \mathrm{kD} \cdot{ }^{[14]}$ The Braf gene is located on the long arm (7q34) of chromosome 7 and consists of 18 exons. The pathological allelic BRAF variants that cause to LS are Thr241Pro and Leu245Phe. Germline mutations in this gene are also associated with cardiofaciocutaneous syndromes and generate somatic mutations..$^{[5,15]}$

\section{RAF1}

When the RAF1 gene is mutated, it causes the resulting RAF1 protein to be constantly active and stimulate other protein kinases in the same signaling pathway that help control cell division. This mutation can cause cells to divide and grow uncontrollably. RAF1 gene mutations are more frequently associated with causing multiple lentigine syndrome and Noonan syndrome than with causing cancer. ${ }^{[16]}$

The heterozygous 1837C> G mutation in the RAF1 gene has been associated with both LEOPARD syndrome and NS. ${ }^{[17]}$ RAF1 is the flux factor of the RAS signal, which encodes the MAPK protein with 648 amino acids in the signal pathway and contains three domains, CR1, CR2 and CR3. Both Noonan syndrome and LEOPARD syndrome are associated with mutations in PTPN11 and RAF1. The percentage of this mutation is higher in patients. Therefore, especially these mutations are paid attention when examining patients. ${ }^{[18]}$

\section{MAP2K1}

This syndrome occurs as a result of a mutation in the 15th chromosome long (q) arm of the MAP2K1 gene. MAP2K1 gene MEK1, protein kinase stimulates to make a protein. This protein is part of a signaling pathway called the RAS/MAPK pathway, which transmits chemical signals from outside the cell to the cell's nucleus. The RAS/MAPK signal helps control the growth and division of cells, specific functions of the cell and the process by which cells mature to perform cell movement and self-destruction (apoptosis) of cells. The MEK1 protein kinase appears to be essential for normal development before birth and for survival after birth. ${ }^{[19]}$

Binding of extracellular ligands such as growth factors, cytokines, hormones and dual specific protein kinase that functions as an essential component of 
the MAP kinase signal transduction pathway to cell surface receptors activates RAS and this initiates RAF1 activation. ${ }^{[20-22]}$

Subsequently, RAF1 also activates the dual specific protein kinases MAP2K1/MEK1 and MAP2K2/ MEK2. Both MAP2K1/MEK1 and MAP2K2/MEK2 function specifically in the MAPK/ERK cascade. A threonine and a tyrosine structure catalyze a tyrosine structure found in the extracellular signal regulated kinases MAPK3/ERK1 and MAPK1. The combination of ERK2, MAPK/ERK cascade leads to activation and further transmission of the signal. BRAF1 activates based on KSR1 or KSR2. Depending on the cellular context, transcription leads to various biological functions such as cell growth, adhesion, survival, and differentiation through metabolism and cytoskeletal rearrangement. The MAP2K1 gene interacts with RAF and BRAF. ${ }^{[20-22]}$

The identified MAP2K1 gene mutation occurs as a result of the replacement of Glutamic acid and Glycerin in the MEK1 protein. This change results in increased activation of the RAS/MAPK signaling pathway in cells throughout the body. Increased signaling interferes with the normal development of many organs and tissues, leading to the characteristic features of Multiple Lentigine Noonan syndrome. ${ }^{[23]}$

\section{OTHER CLINICAL SYNDROMES WITH SIMILAR LEOPARD SYNDROME}

Williams syndrome: There is a microdeletion at 11.23 The long arm of chromosome 7 (q) containing the elastin gene (ELN), $80 \%$ of patients show coronary heart disease (mostly supravalvular aortic stenosis). There is facial dysmorphism (facial anomaly). 15\% of patients have hypercalcemia. A variable degree of mental retardation and developmental delay can also be seen. ${ }^{[24]}$

Watson syndrome: There are Cafe-au-lait (coffee with milk) spots, short stature, mental retardation and pulmonary stenosis. There is a neurofibromin (NF) mutation. Lisch (iris spot) nodule is not expected. ${ }^{[25]}$

Cardiofasiocutaneous syndrome (CFC): There are Congenital heart diseases, LEOPARD and Noonanlike appearance, short stature, mental retardation, ectodermal and gastrointestinal anomalies. It is caused by a spontaneous mutation of all three genes in the mitogen-activated protein kinase (MAPK) pathway. ${ }^{[26,27]}$

Costello syndrome: As in LEOPARD and Noonan syndrome, there is feeding difficulty in infancy.
There are papillomas around the mouth and nose. There is growth retardation and an increased risk of malignancy. There is a mutation in the HRAS gene at 11p13.1. ${ }^{[28,29]}$

\section{Declaration of conflicting interests}

The authors declared no conflicts of interest with respect to the authorship and/or publication of this article.

\section{Funding}

The authors received no financial support for the research and/or authorship of this article.

\section{REFERENCES}

1. Rosen I. Society transactions. Manhattan Dermatology Society. Generalized lentigo. Arch Dermatol Syphilol 1942;45:979-80.

2 Gelb B, Tartaglia M. LEOPARD Syndrome, Multiple Lentigines Syndrome Gene Reviews November 30, 2007; Last Update: May 14, 2015.

3. Gorlin JR, Cohen MM, Levin LS. LEOPARD syndrome. In: Gorlin JR, Cohen MM, Levin LS, editors. Syndromes of the Head and Neck. New York: Oxford University Press; 1990. p. 461-4.

4. Gorlin RJ, Anderson RC, Moller JH. The LEOPARD (multiple lentigines) syndrome revisited. Birth Defects Orig Artic Ser 1971;07:110-5.

5. Sarkozy A, Digilio MC, Dallapiccola B. LEOPARD syndrome. Orphanet J Rare Dis 2008;3:13.

6. Beneteau C, Cavé H, Moncla A, Dorison N, Munnich A, Verloes $A$, et al. SOS1 and PTPN11 mutations in five cases of Noonan syndrome with multiple giant cell lesions. Eur J Hum Genet 2009;17:1216-21.

7. Sithanandam G, Kolch W, Duh FM, Rapp UR. Complete coding sequence of a human B-raf CDNA and detection of B-raf protein kinase with isozyme specific antibodies. Oncogene 1990;5:1775-80.

8. Bentires-Alj M, Paez JG, David FS, Keilhack H, Halmos $B$, Naoki K, et al. Activating mutations of the noonan syndrome-associated SHP2/PTPN11 gene in human solid tumors and adult acute myelogenous leukemia. Cancer Res 2004;64:8816-20.

9. Chan G, Kalaitzidis D, Neel BG. The tyrosine phosphatase Shp2 (PTPN11) in cancer. Cancer Metastasis Rev 2008;27:179-92.

10. Digilio MC, Sarkozy A, de Zorzi A, Pacileo G, Limongelli $G$, Mingarelli $R$, et al. LEOPARD syndrome: clinical diagnosis in the first year of life. Am J Med Genet A 2006;140:740-6.

11. Limongelli G, Sarkozy A, Pacileo G, Calabrò P, Digilio MC, Maddaloni V, et al. Genotype-phenotype analysis and natural history of left ventricular hypertrophy in LEOPARD syndrome. Am J Med Genet A 2008;146A:620-8.

12. Legius $E$, Schrander-Stumpel C, Schollen E, PullesHeintzberger C, Gewillig M, Fryns JP. PTPN11 mutations in LEOPARD syndrome. J Med Genet 2002;39:571-4. 
13. Yoshida R, Nagai T, Hasegawa T, Kinoshita E, Tanaka T, Ogata T. Two novel and one recurrent PTPN11 mutations in LEOPARD syndrome. Am J Med Genet A 2004;130A:432-4.

14. Koudova M, Seemanova E, Zenker M. Novel BRAF mutation in a patient with LEOPARD syndrome and normal intelligence. Eur J Med Genet 2009;52:337-40.

15. Sarkozy A, Carta C, Moretti S, Zampino G, Digilio MC, Pantaleoni F, et al. Germline BRAF mutations in Noonan, LEOPARD, and cardiofaciocutaneous syndromes: molecular diversity and associated phenotypic spectrum. Hum Mutat 2009;30:695-702.

16. Pandit B, Sarkozy A, Pennacchio LA, Carta C, Oishi K, Martinelli $S$, et al. Gain-of-function RAF1 mutations cause Noonan and LEOPARD syndromes with hypertrophic cardiomyopathy. Nat Genet 2007;39:1007-12.

17. Razzaque MA, Nishizawa T, Komoike $Y$, Yagi $H$, Furutani M, Amo R, et al. Germline gain-of-function mutations in RAF1 cause Noonan syndrome. Nat Genet 2007;39:1013-7.

18. Sarkozy A, Obregon MG, Conti E, Esposito G, Mingarelli $R$, Pizzuti A, et al. A novel PTPN11 gene mutation bridges Noonan syndrome, multiple lentigines/LEOPARD syndrome and Noonan-like/multiple giant cell lesion syndrome. Eur J Hum Genet 2004;12:1069-72.

19. Brown NA, Furtado LV, Betz BL, Kiel MJ, Weigelin HC, Lim MS, et al. High prevalence of somatic MAP2K1 mutations in BRAF V600E-negative Langerhans cell histiocytosis. Blood 2014;124:1655-8.

20. Liu X, Yan S, Zhou T, Terada Y, Erikson RL. The MAP kinase pathway is required for entry into mitosis and cell survival. Oncogene 2004;23:763-76.
21. Burgermeister $E$, Chuderland D, Hanoch $T$, Meyer M, Liscovitch M, Seger R. Interaction with MEK causes nuclear export and downregulation of peroxisome proliferator-activated receptor gamma. Mol Cell Biol 2007;27:803-17.

22. Lavoie $H$, Sahmi M, Maisonneuve $P$, Marullo SA, Thevakumaran N, Jin T, et al. MEK drives BRAF activation through allosteric control of KSR proteins. Nature 2018;554:549-53.

23. Nishi E, Mizuno S, Nanjo $Y$, Niihori T, Fukushima $Y$, Matsubara $Y$, et al. A novel heterozygous MAP2K1 mutation in a patient with Noonan syndrome with multiple lentigines. Am J Med Genet A 2015;167A:407-11.

24. Morris CA. Williams Syndrome Synonym: WilliamsBeuren Syndrome April 9, 1999; Last Update: March 23, 2017.

25. Allanson JE, Upadhyaya $M$, Watson $G H$, Partington $M$, MacKenzie A, Lahey $D$, et al. Watson syndrome: is it a subtype of type 1 neurofibromatosis? J Med Genet 1991;28:752-6.

26. Armour CM, Allanson JE. Further delineation of cardio-facio-cutaneous syndrome: clinical features of 38 individuals with proven mutations. J Med Genet 2008;45:249-54.

27. Nyström AM, Ekvall S, Berglund E, Björkqvist $M$, Braathen G, Duchen K, et al. Noonan and cardio-facio-cutaneous syndromes: two clinically and genetically overlapping disorders. J Med Genet 2008;45:500-6.

28. Hennekam RC. Costello syndrome: an overview. Am J Med Genet C Semin Med Genet 2003;117C:42-8.

29. Aoki Y, Niihori T, Kawame H, Kurosawa K, Ohashi H, Tanaka $Y$, et al. Germline mutations in HRAS proto-oncogene cause Costello syndrome. Nat Genet 2005;37:1038-40. 